\title{
Integration Good Psychiatric Management to Psychodynamic Psychotherapy for Fresh Psychotherapists with Treatment of Borderline Personality Disorder
}

\author{
Chang-Hun Lee \\ Leechanghun Psychiatric Clinic, Ulsan, Korea
}

\author{
시작하는 정신치료자의 경계선 성격장애 치료를 위한 좋은 정신과적 관리와 \\ 정신역동적 정신치료의 통합
}

이창훈

이창훈 정신건강의학과의원

\begin{abstract}
Many psychotherapists have experienced limitations in the treatment of borderline personality disorder (BPD). Symptoms of BPD patients sometimes worsened when they were treated with traditional psychoanalytic approaches. Consequently, most psychotherapists have suggested modifications of psychoanalytic methodologies. Over 10 years period, a group of patients whom the psychiatric residents have treated with the psychodynamic psychotherapy for training has moved onto the group of BPD from the one of neurotic disorder. The author perceived that a clear and simple guideline, modified from the traditional psychoanalytic approaches is needed for the psychiatric residents and fresh psychotherapists for initiating treatment of BPD patients with psychodynamic psychotherapy. Good psychiatric management (GPM) is a manualized psychotherapeutic approach with goals for primary and general management of BPD. It has been proven that GPM resolves the pre-existing misbelief and stigma of BPD and proposes a pragmatic and eclectic methodology to help the therapists treat their BPD patients with a more active, optimistic, and positive attitude. The author has suggested in this article GPM can be integrated into the psychodynamic psychotherapy for BPD in terms of the methodology for modifying the psychodynamic psychotherapy treatment approach for BPD. This article includes the principles of the modified psychodynamic psychotherapy as a form of integrating GPM. It will be a guideline for the psychiatric residents and fresh psychotherapists for initiating treatment for BPD patients with psychodynamic psychotherapy.
\end{abstract}

Psychoanalysis 2021;32(3):74-88

KEY WORDS: Borderline personality disorder · Good psychiatric management · Psychodynamic psychotherapy · Fresh psychotherapist · Integration · Psychiatric resident.

Received: April 18, 2021 Revised: May 19, 2021 Accepted: May 25, 2021

Address for correspondence: Chang-Hun Lee, MD

Leechanghun Psychiatric Clinic, 241 Daegongwon-ro, Nam-gu, Ulsan 44667, Korea

Tel: +82-52-265-2051, Fax: +82-52-265-2071, E-mail: drchanghunlee@gmail.com

\section{서 론}

저자는 지난 10 년간 정신과 전공의의 정신역동적 정신치 료를 지도 감독하면서 한 가지 큰 변화에 주목해왔다. 전공

This is an Open Access article distributed under the terms of the Creative Commons Attribution Non-Commercial License (https://creativecommons.org/licenses/by-nc/4.0) which permits unrestricted non-commercial use, distribution, and reproduction in any medium, provided the original work is properly cited.
의들이 정신역동적 정신치료를 시행하는 환자군이 신경증 환자에서 경계성 환자로 점차 기울어진다는 것이다. 경계성 성격장애 환자의 정신역동적 정신치료는 고전적 정신분석 적 방식을 그대로 적용했을 때 효과적으로 치료되기가 어렵 기 때문에, 수십년간 여러 정신치료자들이 수정된 방법론이 필요하다고 주장하였다(Kernberg 2004). 대표적으로 Kern$\operatorname{berg}(2004)$ 는 경계성 성격장애(borderline personality disorder, BPD)의 정신역동적 정신치료가 효과적일 수 있도록 
수정된 정신역동적 정신치료의 원칙을 주장하였다. 그러나 그의 수정된 모델은 여전히 고전적인 정신분석적 치료와 크 게 다르지 않으며, 실제로 $\mathrm{BPD}$ 의 치료에 적용할 때 실용적 이지 않다. 이에 수년 전부터 저자는 경계성 환자의 치료로 첫 정신역동적 정신치료의 경험을 하는 전공의들을 위한 명 확하고 간결한 가이드라인의 필요성을 절감해왔다. 이 논문 은 경계성 환자에게 정신분석적 정신치료를 하는 정신과 전 공의들, 또 $\mathrm{BPD}$ 환자에 대한 경험이 많지 않은 정신치료자 들이 환자를 치료할 때, 치료원칙으로 삼을 수 있는 새로운 모델을 보여준다. 좋은 정신과적 관리(good psychiatic management, GPM)는 $\mathrm{BPD}$ 의 치료법으로서 특수적이고 전문적 인 접근법이 아닌, 일반적, 일차적 치료접근법이다. 저자는 이 모델을 정신역동적 정신치료의 예비면담 단계에 적용한 다면, $\mathrm{BPD}$ 환자가 치료에 전념할 수 있는 치료동기를 고취 하고, 정신역동적 정신치료에 환자가 적합한지 선별하는데 효과적이라는 것을 주장한다. 또한 이를 저자의 임상경험을 통해 뒷받침할 것이다. 이 모델의 실용적, 절충적이며 유연한 자세를 심층적인 정신현상의 의미와 원인을 찾는 고전적 정 신분석적 치료에 통합하여 $\mathrm{BPD}$ 를 위한 보다 효과적인 정신 역동적 정신치료의 모델을 소개한다.

\section{본 론}

의사들은 경계성 성격장애(BPD) 환자를 피하고 싶어할 것이다. 하지만 피할 수 없다. 경계성 성격장애의 유병률은 정신과 내원환자 전체의 약 $20 \%$, 일반인구의 약 $2 \%$ 를 차지 할 정도로 상당히 높다(Gunderson 등 2018; Kernberg와 Michels 2009). 이는 정신분열병이나 양극성장애보다 높은 수 치이다. 그러므로 매일 모든 의료상황에서 경계성 성격장애 환자를 만날 수밖에 없다

경계성 성격장애는 높은 유병률에도 불구하고, 쓰레기통 진단(Knight 1953), 불치병(Clarke 등 1995; Perry와 Cooper 1985; Skodol 등 1983), 골치 아픈 환자라는 이 질환의 사회 적 낙인을 염려하여 진단을 꺼려하는 경향과 DSM-IV에서 성격장애가 AXIS II로 다루어져(American Psychiatric Association 1994) AXIS I의 공존질환에 초점을 두고 이를 일차 진단으로 삼는 경향으로 인해(Bender 등 2001; Kessler 등 1999; Narrow 등 1993; Olfson과 Pincus 1994), 20세기 말까 지 정신의학계에서 큰 주목을 받지 못했다(Oldham과 Skodol 1991; Zimmerman과 Mattiz 1999). 그러나 30여년 전부터 경계성 성격장애로 인한 사회적 경제적 부담이 부각되고, 효 과가 검증된 정신치료법들이 소개되면서 이 질환에 임상의 들의 집중적인 관심이 모이고 있다.
최근 수십년간의 연구 성과로 경계성 성격장애에 대한 오 해와 미신이 해소되고 유용하고 정확한 정보들이 나오고 있 다. 그 핵심은 경계성 성격장애는 흔하며 치료가 가능하다는 것이다(Choi-Kain과 Gunderson 2019a). 효과가 검증된 치 료는 정신치료적 접근으로 변증법적 행동치료(dialectical behavioral treatment, DBT), 마음헤아리기치료(mentalization-based treatment, MBT), 전이초점치료(transferencefocused psychotherapy, TFP), 좋은(일반) 정신과적 관리 [good(general) psychiatric management, GPM]가 대표적이 고 이중 변증법적 행동치료가 가장 보편화되었다(Mercer 등 2019; Gabbard와 Horowitz 2009; Livesley 2012). BPD의 치 료약물로 Food and Drug Administration(FDA)에 승인된 약 물은 아직 없다(Mercer와 Links 2019). 과거에 BPD의 치료로 약물치료가 의미가 있다고 생각되었으나, 최근 연구에서는 약물이 $\mathrm{BPD}$ 의 공존질환의 치료에는 도움이 되지만, $\mathrm{BPD}$ 의 전반적인 심각성을 감소시킨다는 것을 뒷받침하는 근거가 부족하다(Stoffers 2010).

변증법적 행동치료는 $\mathrm{BPD}$ 의 핵심병리를 감정조절장애로 보고 인지행동 치료적으로 접근하고(Linehan 1993), 마음헤 아리기치료는 자신과 다른 사람의 마음에 어떤 일이 일어나 는지를 이해하는 정신화 기능의 장애가 $\mathrm{BPD}$ 의 핵심병리라 고 보고 애착이론을 바탕으로 인지적, 정신역동적으로 접근 한다(Bateman과 Fonagy 2004, 2016). 전이초점치료는 BPD 환자의 공격성과 원초적 방어에 초점을 두어 직면과 전이해 석을 통해 대상관계의 왜곡을 회복시키는 정신역동적 접근 법이다(Hersh 2019; Yeomans 2015). 이 접근법들은 각각의 매뉴얼을 개발하여 훈련생들에게 포괄적이고 방대한 지식 을 효과적으로 교육하고 치료에 구조를 제공하여 실제 임상 에서 실현이 용이하도록 했다. 이러한 특수화된 정신치료법 을 훈련하기 위해서는 각각의 기관에서 평균 1 년 정도의 훈 련기간을 요구하고(Behavioral Tech 2021), 환자의 치료는 일반적으로 2년 이상을 예상한다(Yeomans 2015).

이에 반해 좋은(일반) 정신과적 관리(GPM)는 $\mathrm{BPD}$ 의 치료 로 장기적인 특수 치료만이 효과가 있는지에 대해 의문을 제 기한다. $\mathrm{BPD}$ 의 10 년간의 자연경과 추적연구를 통해 치료 없 이도 호전이 된다는 결과를 제시하여(Gunderson 등 2011; Zanarini 등 2012) BPD가 치료하기 힘든 질환이 아니라고 강 조한다. 자살성향, 공격 충동성, 감정의 불안정성 등의 급성증 상은 장기적인 특수치료가 아니어도 일반적인 정신과적 접 근을 통한다면 충분히 호전되므로(Bateman 2012), 모든 정 신건강관련 전문가들이 이미 “충분히 좋은(Good Enough)” 치료자라고 주장한다(Choi-Kain과 Gunderson 2019b). 실 제로, 일반 정신과적 관리의 효과가 장기간의 특수치료와 비 
교연구에서 유의미한 차이가 없다는 연구결과들이 있었다 (McMain 등 2009, 2012).

$\mathrm{BPD}$ 의 치료에 효과가 검증된 여러 특수치료법이 있고 더 구나 GPM에서는 일반적인 정신과적 관리로 급성증상의 호 전이 가능하다는 주장을 감안할 때, 전공의들이 경계성 환자 를 굳이 정신역동적 정신치료로 치료해야 하는가 하는 질문 이 가능하다.

우선 정신역동적 정신치료 또한 $\mathrm{BPD}$ 의 치료로 효과가 검 증이 되었다(Haskayne 등 2014; Kernberg와 Michels 2009). 비구조화된 치료의 특성상 비교연구가 수월하지 않기 때문 에 효과검증을 위한 임의대조군 실험의 대상으로 채택되지 못했던 경향이 있을 뿐이다. 정신분석적 정신치료는 신경증 환자뿐 아니라 좀 더 병리가 심한 경계성 환자들에게도 이미 근본적인 치료(radical treatment)로 실행되어왔다. 정신분석 적 정신치료는 비구조화된 치료로 자유연상과 전이와 저항, 방어의 해석이라는 기본이론의 토대 위에 환자와 치료자 사 이의 고유한 상호작용을 선입견 없이 이해하는 것이 핵심개 념이다(Kernberg 2004). 이는 각 환자의 개별화, 주체화, 정체 성의 확립을 성취하는 인간의 궁극적인 목표를 지향한다.

어떤 $\mathrm{BPD}$ 환자들은 구조화된 정신치료와 인지적, 행동적 치료법이 자신에게 적합하지 않거나 자신의 필요를 채우기 에 부족함을 느낀다. 그러한 치료법들은 마치 규격화된 대량 생산품을 보급하는 것처럼 각각의 환자들에게는 자신만을 위한 맞춤치료로 느껴지지 않을 수 있다. 매뉴얼화된 치료 는, 전자제품 설치 매뉴얼을 예를 들면, 컴퓨터의 작동원리를 다 알 필요 없이 매뉴얼만 따라가면 설치가 되는 것처럼, $\mathrm{BPD}$ 에 심도 깊은 이해와 경험이 없어도 비교적 간략한 훈련 을 거쳐서 치료할 수 있도록 한 것이다. 그렇기 때문에 비용 대 효과 면에서는 우수한 치료법이라고 할 수 있지만, 만성적인 병리와 환자의 기능에는 치료효과가 제한적이고, 환자의 내적 변화를 기대하기 어렵다는 한계가 있다(Davinson 등 2010; Bateman과 Fonagy 2008; Kernberg와 Michels 2009; McMain 등 2012; Zanarini 등 2010). 보다 근본적인 이해와 변화를 필 요로 하는 환자들에게는 정신역동적 정신치료가 가장 적합하 고 효과적인 치료가 될 수 있다. 따라서 정신역동적 정신치료 혹은 정신분석적 정신치료는 $\mathrm{BPD}$ 환자의 치료에서 여전히 중요한 위치에 있다. 그런데, 앞서 언급한 바와 같이, 고전적 인 정신분석 기법을 그대로 정신분석적 정신치료에 적용하 는 경우, 경계성 환자의 치료에 효과적이지 않다는 것이 관찰 되어왔다(Kernberg 2004; Kernberg와 Michels 2009; Livesley 2012). 이렇게 정신분석적 접근의 한계를 경험하면서 1990년대부터 BPD에 특화된 매뉴얼화된 정신치료들이 집 중적으로 개발, 보급이 되기 시작했다고 할 수도 있다.
정신분석 치료자들은 고전적인 정신분석적 치료에서 치료 자의 익명성과 중립성을 강조하고 전이와 저항의 해석과 생 의 초기경험의 재구성을 중심으로 하는 치료가 $\mathrm{BPD}$ 환자를 오 히려 악화시키기도 한다는 것을 경험했다(Kernber 2004; Kernber와 Michels 2009). 치료자의 익명성과 뒤로 물러난 태 도가 환자의 유기불안을 자극하고, 비구조화된 환경은 환자 를 담아주는(containing) 기능을 하지 못해 환자를 혼란스럽 게 할 수 있었다. 그리하여 정신분석적 정신치료를 $\mathrm{BPD}$ 환자 에게 적합하게 수정하여 적용하려고 노력했다. Otto Kernberg가 대표적인데, 그의 수정된 정신분석적 정신치료의 원 칙은 익명의 치료자 역할에서 벗어나 적극적인 치료자의 자 세, 좀 더 지지적인 태도, 환자-치료자의 치료동맹의 확립을 위해 치료자가 보다 적극적으로 개입하고, 유아기의 경험보 다는 지금-여기에 초점을 맞춘 전이해석, 치료자의 역전이 를 이용하여 환자의 감정과 치료관계에서의 전이감정을 이 해하려는 적극적인 노력, 교육적인 요소의 결합을 골자로 한 다(Kernberg 2004; Kernber와 Michels 2009)(Table 1).

저자는 정신분석적 정신치료의 수정을 위한 하나의 실용 적인 대안으로 Gunderson과 Links(2014)에 의해 개발된 '좋 은 정신과적 관리(GPM)'의 이념과 핵심개념을 정신역동적 정신치료에 통합할 것을 제안한다. GPM은 BPD에 대한 일 차적 접근을 목적으로 하는 치료법으로 경험이 부족한 전공 의나 초심자인 치료자들이 $\mathrm{BPD}$ 환자를 처음 접할 때 평가 하고 치료를 계획하는 단계에서 유용하다. 그리고 Otto Kernberg가 주장한 치료자의 보다 적극적이고 지지적인 태 도와 교육적인 요소의 결합이 필요하다는 측면에서 $\mathrm{GPM}$ 은 매우 구체적이고 실용적인 방법론을 제시하고 있다.

저자는 우선 GPM의 핵심개념을 간략히 설명할 것이다. 이 부분은 $\mathrm{GPM}$ 을 소개하고 요약하는 것이 될 것이며, 그 다 음에 저자가 주장하는 정신역동적 정신치료를 $\mathrm{BPD}$ 의 치료 에 효과적으로 수정한 새로운 원칙을 설명할 것이다. 이는 유용한 GPM의 개념들을 정신역동적 정신치료에 통합하여 경계성 성격장애의 치료에 효과적으로 수정한 것이다.

\section{좋은 정신과적 관리의 핵심 원칙}

좋은 정신과적 관리(GPM)는 John Gunderson이 $\mathrm{BPD}$ 환자 를 위한 보편적이고 실용적인 치료로 고안한 치료법이다

Table 1. Modified principles of psychodynamic psychotherapy for borderline personality disorder by Otto Kernberg

1. Active and supportive therapist's attitude

2. Focus on here and now

3. Use of therapist's countertransference

4. Implication of educative aspects 
(Choi-Kain과 Gunderson 2019a; Gunderson과 Links 2014). 원래 일반 정신과적 관리(GPM)라고 불렸으나, 이 치료의 대 중화를 위해 그는 보다 쉽고 흥미로운 새 이름-'good' psychiatric management 을 붙였다. Gunderson은 경계성 성 격장애는 치료가 힘들며 장기적인 특수치료가 필요하다는 오해와 미신을 타파하고 정신과 의사뿐 아니라 정신건강 관 련 전문가라면 누구나 BPD 환자의 치료를 위한 대부분의 기 술과 지식을 이미 습득하고 있다고 생각했다. 단 하루 워크 샵의 일정으로 좋은 정신과적 관리의 핵심개념과 기법에 대 해 습득하면 모두가 $\mathrm{BPD}$ 환자를 위한 충분히 좋은 치료자가 되기에 충분하다고 주장한다.

좋은 정신과적 관리의 핵심원칙은 진단의 공유, 대인관계 과민감성과 유전성에 대한 심리교육, 치료자의 적극적, 지지 적, 선제적 자세, 실용적이고 단계적인 치료전략, 치료관계 보다는 실생활의 문제에 초점을 맞춘 선제적인 접근이다 (Table 2).

\section{진단의 공유}

$\mathrm{GPM}$ 뿐만 아니라 $\mathrm{BPD}$ 환자의 근거기반 정신치료는 모두 진단을 공개할 것을 권한다. GPM은 치료자가 환자와 함께 DSM-5 BPD 진단 범주를 살펴보면서 한 항목씩 검토해 나 갈 것을 권한다. $\mathrm{BPD}$ 환자가 자신의 질환에 대해 선이해를 가지고 있는 것이 여러 면에서 환자에게 도움이 된다. $\mathrm{BPD}$ 는 국내에서 여전히 진단내리기 꺼려하는 질환이어서 일반 인들 사이에 널리 알려져 있지 않다. 인터넷에서 검색되는 정 보들은 BPD에 대한 오해와 낙인을 찍는 내용들이 대부분으 로 환자들이 자신의 질환에 대해 전혀 다른 이해를 하게 하고 치료에 접근하는 것을 막는 요인이 되고 있다. 그러므로 정확 한 진단을 환자에게 공개하고 올바른 정보를 제공하는 것이 질환에 대한 낙인과 부정적 인식을 가지게 되는 것을 예방하 고 환자가 치료에 긍정적인 태도를 견지하도록 돕는다.

대부분의 $\mathrm{BPD}$ 환자들이 진단 공유 과정에 호의적이고 적 극적이며 수용적이다. 자신의 증상이 $\mathrm{BPD}$ 범주에 정확하게 맞다는 것을 확인하면 환자들은 대개 정확한 진단을 알게

Table 2. The essential principles of good psychiatric management

1. Disclosure and sharing diagnosis-first essential step

2. Interpersonal hypersensitivity

3. Psychoeducation-prevalence, hereditability, natural course, therapeutic options, comorbidity of borderline personality disorder

4. Therapist's active, supportive and proactive attitude

5. Eclectic and stepwise approach

6. "Get a life"
되었다는 것에 안심한다. 그 후에 이 질환의 유병률이 높으 며 효과적인 치료법이 여러 가지 개발되었다는 것을 교육하 면 환자들은 자신만 아주 큰 문제를 가지고 있는 것이 아닐 까 하는 두려움과 죄책감, 외로움에서 다소 해방될 수 있다.

\section{대인관계 과민감성과 유전성}

$\mathrm{GPM}$ 은 대인관계 과민감성을 핵심병리 모델로 채택한다. $\mathrm{BPD}$ 성격장애 환자들은 대인관계에서 거절과 버림받음에 과민감한 유전적 소인을 가지고 태어났다는 관점이다(ChoiKain과 Gunderson 2019a; Gunderson과 Lyons-Ruth 2008). 이 환자들은 사람들과 연결되어 있고 돌봄을 받는다고 느낄 때에는 협조적이고 대상을 이상화한다. 하지만 이때도 역시 거절에 민감하고 공허함과 우울감을 느낀다. 그런데 관계에 서 거절감을 느끼게 되면 쉽게 분노하고 상대를 비난하게 된 다. 또 스스로 심한 자책을 하고 상대를 마음대로 조정하려고 애쓰게 된다. 이런 상태가 회복되지 못하고 오래 지속된다면 환자는 고립되어서 편집증적인 사고와 충동적인 행동을 하 고 공격적이며 자해 및 자살시도를 하게 된다(대인관계 일관 성 모델, interpersonal coherence model)(Figure 1, Table 3).

대인관계 과민감성 모델과 유전성은 GPM의 심리교육에 서 중심적인 부분이다. 환자의 반복되는 대인관계에서의 문 제를, 이 모델을 적용하여 명료하게 설명한다. 정신치료 전

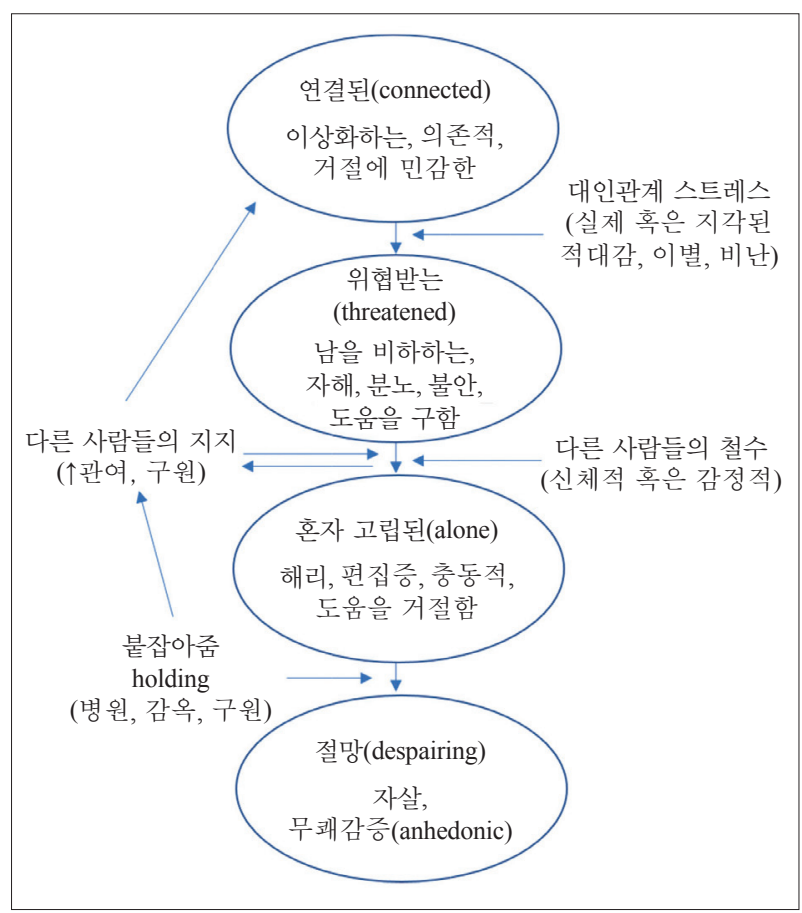

Figure 1. Interpersonal coherence model. Adapted from Choi-Kain and Gunderson. 모든 상황에서 적용가능한 경계선 성격장애를 위한 좋은 정신과적 관리. 이창훈, 이정우, 정자현, translator. Seoul: 하나의 학사;2020. p.452, with permission of 하나의학사. 
Table 3. Interpersonal coherence model

\begin{tabular}{|c|c|}
\hline & \\
\hline $\begin{array}{l}\text { 연결된 } \\
\text { (connected) }\end{array}$ & $\begin{array}{l}\text { 환자는 이상적 관계가 붙잡아주고 있다고 느낀다. 이런 연결된 상태에서는 } \\
\text { 거절에 민감하다. }\end{array}$ \\
\hline & \\
\hline $\begin{array}{c}\text { S소 } \\
\text { (a) }\end{array}$ & $\begin{array}{l}\text { al)하는 행동을 하게 되면, 환자는 더욱 } \\
\text { 을 받기가 더 힘들어진다. }\end{array}$ \\
\hline 망 & 고, 정말 혼자이면 환자는 우울해 \\
\hline \multicolumn{2}{|c|}{$\begin{array}{l}\text { 보듬어주는 환경(holding environment)은 환자가 의지할 수 있다고 느끼고 환자를 진정시킬 수 있는 관계를 말한다. 타인이 } \\
\text { 일관된 관심과 반응을 보이면, 환자는 그가 자신을 돌본다는 믿음이 생기게 된다. 위협을 느낀다면, 공격적인 행동을 통해 자 } \\
\text { 신의 보호자로부터 관심을 끌 수 있다. 보호자가 구해주고 더 관심을 보여주면 환자는 진정이 되고 다시 연결된 상태로 되돌 } \\
\text { 아간다. 그러나 환자가 혼자가 되고 절망감에 빠지면, 외부의 컨데이너(container)가(예, 병원, 감옥) 보호자나 외로움을 해소시 } \\
\text { 쳐주는 지지자가 해주는 담아주기(containment)를 제공한다. Adapted from Choi-Kain and Gunderson. 모든 상황에서 적용가능 } \\
\text { 한 경계선 성격장애를 위한 좋은 정신과적 관리. 이창훈, 이정우, 정자현, translator. Seoul: 하나의학사;2020. p.452, with per- }\end{array}$} \\
\hline
\end{tabular}

체를 통틀어 대인관계 과민감성에 대한 교육을 반복하고 악 화가 예상될 때 선제적으로 이 모델을 활용하여 환자에게 필 요한 지지와 붙들어 줌(holding)을 제공하고 환자가 자신의 상태를 알아차릴 수 있도록 하여 악화를 예방한다.

\section{심리교육}

$\mathrm{GPM}$ 은 진단과 유전성, 질환의 경과, 동반질환, 치료접근 법에 대한 심리교육을 강조한다. 심리교육은 예비면담 동안 이나 교육 세션을 따로 잡아서 시행할 수도 있겠고, 정신치료 전체 과정을 통해 각 항목에 대해 시의적절하게 시행할 수도 있다. 질환의 경과에 대해서는 10 년 자연경과에서 $80 \%$ 가 관 해에 이르고, 하지만 사회적 기능에서의 호전은 잘 일어나지 않는다는 것을 교육한다(Gunderson 등 2011; Zanarini 등 2012). 동반질환에 대한 교육은 $\mathrm{BPD}$ 는 $\mathrm{BPD}$ 단독 진단이 거 의 없을 정도로 동반질환 유병률이 매우 높으며, 동반질환에 따라 $\mathrm{BPD}$ 의 치료가 우선적일 수도 있고 동반질환의 치료가 우선적일 수도 있다는 것이다.

\section{치료자의 적극적, 지지적, 선제적인 자세}

$\mathrm{GPM}$ 은 치료자가 반사적(reactive)이지 않고 적극적(active)일 것을 강조한다. 이것은 모든 $\mathrm{BPD}$ 의 치료법에서 치 료자에게 요구하는 원칙이다. 치료자가 환자의 마음을 궁금 해하고 환자의 이야기를 경청하며, 반응적(responsive)인 태 도로 상호작용하는 것은 환자-치료자 관계에서 치료동맹을 강화하는 데 매우 중요한 역할을 한다. 또 $\mathrm{GPM}$ 의 치료자는 적극적인 태도로 환자의 수동성, 침묵, 회피에 도전한다. 치 료자의 적극적이고 지지적인 태도는 혼란스러운 환자의 감 정을 담아주는(holding \& containing) 기능을 한다. 환자는 치료자가 제공하는 안전한 심리적 공간에서 안정화되어 자
신을 성찰하는 기회를 가질 수 있다.

환자의 투사(projection)를 담아주는(containing) 컨테이 너로서의 역할을 하기 위해 사려깊고 조심스러운 태도도 동 시에 요구된다. 환자를 공감하고 이해하는 태도로 대하는 것 은 기본 원칙이다. 그러나 이것은 환자의 모든 것에 동의하 는 것이 아니다. 때로는 '잘 모르겠다(not knowing)'는 태도 가 필요하며 치료자와 환자는 이해하기 위해 함께 작업한다.

또 $\mathrm{GPM}$ 은 한발 더 나아가서 환자의 문제점과 예견되는 어려움을 파악하여 예방할 수 있도록 치료자가 선제적(proactive)인 자세를 가질 것을 주문한다. $\mathrm{BPD}$ 환자들이 관계에 집착하는 것을 지양하고 자신의 가치와 자존감을 높이고 정 체성을 성장시키기 위해 학업이나 일에서의 성취에 보다 초점 을 두도록 조언하고 교육한다. 이처럼 GPM은 '사랑 이전에 일'이라는 슬로건을 제시한다. 환자의 실생활의 어려움에 대 한 사례 관리적인 접근도 $\mathrm{GPM}$ 의 특징적인 선제적 접근이다.

\section{절충적, 단계적 접근}

$\mathrm{GPM}$ 은 매우 유연하고 실용적인 이념을 가지고 있다. 즉, 치료에 도움이 되는 모든 개념을 통합, 절충하려고 한다. $\mathrm{DBT}$ 에서는 문제해결 기술훈련 방식과 연쇄분석, 숙제를 내 주고 확인하기, 삶을 찾자는 목표를, $\mathrm{MBT}$ 에서는 '잘 모른다' 는 자세, theory of mind의 개념을, TFP에서는 분노에 초점 을 두고 부정적 전이를 해석하는 기법을 빌려와 절충한다.

또 단계적 관리 모델로서 환자의 필요와 증상의 심각도에 따라서 일차적이고 보다 보편적인 치료접근법에서 시작하 여, 집중적이고 특수화된 치료를 통합한 접근법에 이르기까 지 단계적으로 치료전략을 세울 것을 권고한다(Figure 2). 치료의 빈도와 기간도 환자의 필요와 치료의 효과, 증상의 심각도에 따라 매우 유연하게 조절할 수 있다. 


\begin{tabular}{|c|c|c|c|}
\hline & 심각도 & 정의 & 잠재적 개입들 \\
\hline $\begin{array}{l}5 \text { 만성적 } \\
\text { 지속적 }\end{array}$ & $\begin{array}{l}\text { 호전없는 장애 } \\
\text { 개입에 반응하지 않음 }\end{array}$ & $\begin{array}{l}\text { 심각도와 복잡성으로 인해, 혹은 } \\
\text { 치료 비순응으로 인해 이전 } \\
\text { 단계부터의 개입에 반응하지 } \\
\text { 않음 }\end{array}$ & $\begin{array}{l}\mathrm{GPM} \text { (주1회, 월1회, 매분기1회) } \\
\text { 지지 치료 } \\
\text { 사례 관리(정부/공공 서비스) }\end{array}$ \\
\hline 4 중증 & 완해와 재발 & $\begin{array}{l}\text { +심각한 자해 } \\
\text { +잠재적인 치명적 자살 시도 }\end{array}$ & $\begin{array}{l}\mathrm{GPM}(+ \text { 약물 치료 })+ \\
\text { 집중적인 케어 } \\
\text { 근거기반의 치료와 통합하거나 근거기반의 } \\
\text { 치료로 전환 }\end{array}$ \\
\hline 3 지속되는 중등도 & $\begin{array}{l}\text { 지속되는 역치 수준의 } \\
\text { 증상들 }\end{array}$ & $\begin{array}{l}\text { 기본적 치료에 반응이 없음 } \\
+ \text { 자해 } \\
\text { +자살 제스처 }\end{array}$ & $\begin{array}{l}\mathrm{GPM}(+ \text { 약물 치료 })+ \\
\mathrm{DBT} \text { 기술, } \mathrm{MBT}, \mathrm{TFP} \text { or 이용가능할 경우 } \\
\text { STEPPS 그룹 }\end{array}$ \\
\hline 2 초기 경증 & 경한 $\mathrm{BPD}$ 의 첫 삽화 & $\begin{array}{l}\text { +자해 } \\
\text {-자살위험성 }\end{array}$ & $\begin{array}{l}\mathrm{GPM} \\
\text { 사례관리 } \\
\text { DBT 기술, MBT, or 이용가능할 경우 STEPPS } \\
\quad \text { 그룹; self-help }\end{array}$ \\
\hline 1 전임상기 & 역치 하 수준 & $\begin{array}{l}\text { 대인관계 과민감성 } \\
\text { 거절에 민감함 } \\
\text { 감정조절장애 }\end{array}$ & $\begin{array}{l}\text { 심리교육, 건강정보 이해능력 교육 } \\
\text { 대인관계 과민감성과 거절에 민감함을 } \\
\text { 다루는 문제해결과 지지적 카운셀링에 초점 }\end{array}$ \\
\hline
\end{tabular}

Figure 2. Stepped care model. DBT: dialectical behavioral treatment, GPM: good psychiatric management, MBT: mentalization-based treatment, STEPPS: Systems Training for Emotional Predictability and Problem Solving, TFP: transference-focused psychotherapy. Adapted from Choi-Kain and Gunderson. 이창훈, 이정우, 정자현, translator. Seoul: 하나의학사;2020. p.452, with permission of 하나의학사.

\section{삶을 찾자(Get a life)}

이는 DBT의 핵심목표로 GPM에서도 일상생활에서의 문 제점에 초점을 맞춘다. 이미 설명한 바와 같이 대인관계와 직 업적 기능에서의 장애가 $\mathrm{BPD}$ 의 주된 만성적 장애이며, 이를 해결하기 위해 우선 직업적 기능을 향상시킬 것을 강조한다. 일은 스스로를 돌보는 것이며, 일을 통해 자신의 가치를 높인 다면 대인관계의 장애를 보다 쉽게 극복할 수 있다.

여기까지 좋은(일반) 정신과적 관리의 핵심원칙을 간략하 게 살펴보았다. $\mathrm{GPM}$ 은 $\mathrm{BPD}$ 의 일차적 치료를 위해 고안되 었고 실생활에서의 문제점에 초점을 맞추고 있다. 보다 심층 적이고 내면적인 치료접근인 정신역동적 정신치료와 얼핏 보기에 상반된 개념을 가지고 있는 것처럼 보이나, $\mathrm{BPD}$ 의 효과적인 치료를 위해 정신역동적 정신치료를 수정하려 할 때, 유용하게 절충, 통합할 수 있는 요소를 포함하고 있다.

저자는 $\mathrm{GPM}$ 이 $\mathrm{BPD}$ 를 위한 일차적 치료로 고안된 만큼 경험이 부족한 전공의나 초심자 치료자들이 $\mathrm{BPD}$ 환자를 평 가하고 치료를 계획하는 단계에서 유용한 접근법이라고 생 각한다. 이제 저자는 $\mathrm{GPM}$ 의 핵심개념을 절충, 통합한, 새로 운 수정된 정신역동적 정신치료의 원칙을 제안하려고 한다 (Table 4). Otto Kernberg가 제안한 BPD 치료를 위한 수정 된 역동정신치료에서 간과하고 있는 부분인 $\mathrm{BPD}$ 환자의 예 비면담, 환자의 심리교육적인 측면, 실용적인 적용을 강조하 여 설명하는 치료모델이 될 것이다. 이 새로운 모델은 치료 적 이론이나 기법에서의 새로운 방향을 제시하기 위한 것은
아니다. 고전적인 정신분석적 이론과 지금까지 $\mathrm{BPD}$ 환자에 게 적합하게 수정되어온 기법적인 원칙은 따르되, 실제 임상 에서 정신분석적 치료를 실현하는 데 실용적이지 않았던 부 분들을 수정하고 보완하여 보다 현실적이고 적용가능한 치 료모델을 제시하려는 것이다.

\section{경계성 성격장애의 치료를 위해 수정된 정신역동적 정신치료의 원칙-GPM의 통합}

\section{예비면담을 적극적으로 활용하라}

정신역동적 정신치료에서의 예비면담은 환자에게 정신역 동적 정신치료가 유용할 것인지를 평가하고 치료자가 환자 에 대해 알아가고 환자를 준비시키기 위한 기간이다. 전공의 나 초심자 정신치료자들이 예비면담을 환자의 병력을 청취 하는 시간으로 여기고 예비면담을 시작하기 전부터 무조건 정신역동적 정신치료를 시작할 것으로 마음을 정해놓고 시 작하는 것은 예비면담의 중요한 기능을 놓치는 실수를 하는 것이다.

환자의 증상을 평가하고, 환자와 치료자가 친숙해지고, 환 자가 치료에 적응하는 것이 예비면담의 기능이므로, 이 예비 면담 시간을 GPM의 일차적 치료접근으로 활용한다고 여겨 도 무방할 것이다. 즉, 예비면담 시간에 환자의 진단을 공유하 고 질환의 경과와 증상, 치료에 대한 심리교육을 시행할 수 있다. 또 환자의 병력을 경청한 후, $\mathrm{BPD}$ 가 주 진단으로 판단 
Table 4. The newly modified principle of psychodynamic psychotherapy for BPD; by integration good psychiatric management to dynamic psychotherapy

1. Use preliminary sessions actively

a. Share diagnosis

b. Disclosure severity and evaluation of patient's symptoms

c. Use preliminary sessions as the primary therapeutic approach and as a tool for improving patient's motivation

d. Cooperate with patient in choosing treatment methods and managing comorbidity

e. Careful to decide whether you start the psychodynamic psychotherapy or not

f. Psychoeducation-prevalence, hereditability, natural course, comorbidity

g. Explain the primary hypothesis-psychoeducation about interpersonal hypersensitivity

h. Must have the supervision

2. Open mind to flexible settings

a. Flexibility with frequency and duration of treatment

b. Safety management-patient has the primary responsibility to his/her safety

c. Careful judgement about medication and hospitalization

d. Cooperation with family or caretakers.

3. Active attitude of therapist

a. Have a confidence as 'Good enough' therapist

b. Establish therapeutic alliance

c. Supportive attitude

4. Show empathy and listen authentically

5. Focus on here and now

a. Focus on the interaction between patient and therapist

b. Use confrontation, interpretation, and transference interpretation

6. Attention on real-life problems

7. Use therapist's countertransference

8. Accept the various treatment approaches-have acceptive and comprehensive attitude toward various and new perspectives about BPD

BPD: borderline personality disorder

된다면 환자의 역동가설을 설명할 때 대인관계 과민감성 모 델을 이용할 수 있다(Figure 1). 정신역동적 가설에 익숙하 지 않은 전공의나 정신치료자에게는 GPM의 대인관계 과민 감성 모델은 쉽고 훌륭한 역동가설로 이용할 수 있다.

\section{진단공유}

환자의 진단이 $\mathrm{BPD}$ 라고 평가한다면, 환자와 $\mathrm{DSM}-5$ 진 단 범주를 함께 보면서 한 항목, 한 항목을 검토한다. 한 항 목씩 읽고 그런 면이 있는지 환자에게 물어본다. 만약 $\mathrm{DSM}$-5의 진단기준의 항목이 환자에게 와닿지 않는 것 같 다면, DSM-5 섹션 III에 있는 대안적 진단모델을 이용하는 것도 좋을 것이다. 많은 치료자들은 환자들이 $\mathrm{BPD}$ 진단에 선입견을 가지고 거부할 것이라고 염려하지만, 실상은 그렇 지 않다. 환자들은 진단기준의 항목을 하나씩 검토하면서 자 신의 증상이 기술된 방식을 보고 매우 공감하거나 자신의
증상을 이렇게 기술할 수 있을지 깊이 고민하는 태도를 보 이곤 한다. 진단기준의 항목들을 검토하는 것 자체가 훌륭한 성찰의 기회가 된다.

$\mathrm{BPD}$ 로 진단되는 대부분의 환자들은 진단기준의 항목을 검토할 때 자신의 상태를 아주 잘 표현해주는 문장이라고 생각하고 진단에 동의한다. 자신의 어려움을 잘 정리된 문장 으로 표현해준 진단기준을 보고 환자들은 안심한다. 왜냐면 자신의 문제가 설명할 수 없는 이상한 것이 아니라 이렇게 설명과 이해가 가능한 것이라고 느끼기 때문이다. 주변사람 들로부터 이해받지 못하고 특이한 성격의 소유자로 치부되 어 소외된 경험들이 있기 때문에 자신이 $\mathrm{BPD}$ 진단기준에 맞는다는 것이 오히려 질환군의 공동체에 포함되는 느낌을 주기도 할 것이다.

치료자가 $\mathrm{BPD}$ 의 진단을 공개하기 꺼려하여 우울증이라 는 모호하고 친숙한 진단을 제시하는 경우가 많다. 이런 경 
우의 문제점은 환자뿐 아니라 치료자 또한 왜곡된 진단명을 은연중에 받아들여 약물치료를 일차적인 치료로 여기게 된 다. 이때 치료효과가 없는 것이 당연하다. 그런데도 치료자 는 치료효과가 없으면 복수약물을 처방하거나 용량을 지나 치게 높여 처방하게 된다. 이런 환자들이 여러 진료기관을 전전하면서 점차 처방약물은 복잡하고 고용량이 되며 환자 의 진단은 더욱 모호해지는 악순환을 겪게 된다.

만약 경계성 성격장애라는 진단명이 여전히 낙인을 줄 수 있다고 걱정이 된다면, 경계성 성격장애라는 진단명을 대신 해 '경계성 장애'라고 명명하는 것도 대안이 될 수 있다. 환 자는 경계성 장애가 경계성 성격장애를 의미한다는 것을 알 고 있지만, 경계성 장애라고 불릴 때 '성격장애'라는 말의 어 감에서 주는 부정적인 이미지를 덜 느낄 수 있다.

환자와 진단을 공유하는 것이 치료의 교착상태를 극복할 수 있도록 도왔던 한 증례를 제시하겠다. 저자가 수년간 정 신분석을 했던 한 $\mathrm{BPD}$ 환자가 치료의 교착상태에 빠져 더 이상의 진전이 없었다. 급기야 치료는 중단되고 말았다. 수 년간의 치료 동안 환자는 자신의 병이 우울증이라고 생각하 고 있었지만, 저자는 익명성을 지킨다는 생각으로 환자의 진 단을 한 번도 말한 적이 없었다. 수개월 후 환자는 우울증이 심해졌다고 하며 다시 치료를 찾았다. 당시 $\mathrm{BPD}$ 환자에게 효과적인 치료모델로 GPM과의 통합을 생각하고 있던 저자 는, 다시 찾아온 환자에게 서너 세션을 걸쳐 진단을 공유하 고 치료경과와 치료선택지에 대한 심리교육을 했다. 환자는 자신이 치료를 처음 시작했을 당시, 경계성 성격장애의 진단 범주에 맞았다는 것을 깨달았고, 더불어 자신이 호전된 부분 과 여전히 장애가 있는 부분에 대해 분리하여 이해하게 되 었다. 자살성향과 충동성, 감정의 불안정성은 많이 호전되었 지만, 여전히 자기파괴적인 행동이 미묘하게 지속되고 자신 의 일상을 독립적으로 살아가지 못하다는 것을 인식했다. 환 자는 주 2 회의 정신역동적 정신치료로 치료를 재개하는 것 에 동의했고 전보다 치료동기가 더 향상된 것을 여러 면에

\section{Table 5. Psychoeducation for BPD}

\section{$\mathrm{BPD}$ is not rare}

BPD has the high hereditability

Most of BPD have the comorbidities

BPD's symptoms naturally alleviate as times go on

Psychotherapeutic approaches are the only one which is evidence-based treatment for BPD

No drug has been proved its effect for improving BPD's general symptoms

We should evaluate careful the need for medication and hospitalization

BPD: borderline personality disorder
서 보여주었다. 저자는 환자가 이전 치료에서보다 치료자와 동등한 지위에서 대화를 하기 시작했다는 것을 느꼈는데, 이 는 진단을 환자와 공유했던 행위가, 치료자가 모든 권한과 정보를 손에 쥐고 환자를 통제하는 것으로 비춰졌던, 치료자 에 대한 환자의 인식에 변화를 일으키게 했기 때문이라고 생각했다. 이처럼 진단의 공개가 환자에게 낙인을 줄 것이라 는 기존의 우려와는 전혀 다른 결과를 보여준 예가 되겠다.

\section{심리교육}

진단공유와 함께 질환에 대한 올바른 정보를 제공할 필요 가 있다. 미디어를 통해 $\mathrm{BPD}$ 에 대한 잘못된 정보가 전달되 는 면이 있기 때문에 $\mathrm{BPD}$ 환자에게 치료자가 올바른 정보 를 교육하는 것은 매우 중요하다(Table 5).

우선 $\mathrm{BPD}$ 는 드물지 않다는 것이다. 일반인구의 유병률이 $2 \%$ 6\% 정도가 되며 정신과 외래에서 차지하는 비율은 $20 \%$ 정도가 된다(Gunderson 등 2018; Kernberg와 Michels 2009). 이는 정신분열병이나 조울증보다 더 높은 유병률이다. 그리 고 $\mathrm{BPD}$ 는 유전적인 질환이라는 것이다. Reichborn-Kjennerud 등(2013)은 BPD의 유전성이 55\%에 달한다는 연구결 과를 발표했다. 이 사실은 지금까지 $\mathrm{BPD}$ 의 주된 원인이 부 모의 잘못된 양육이나 환경일 것이라고 추정해왔던 관점에 새로운 시각을 요구한다. 이 질환의 탓을 부모나 양육자에게 돌리거나 문제를 가지고 있는 환자를 비난하는 태도가 있었 고 그것이 $\mathrm{BPD}$ 의 사회적 낙인이 되어, $\mathrm{BPD}$ 환자와 가족 모 두에게 부당한 죄책감을 주었던 것은 사실이다. $\mathrm{BPD}$ 가 유 전성이 꽤 높은 질환이라는 사실은 이러한 사회적 편견을 바로잡을 필요가 있다는 것을 시사한다. 그러나 유전성이 높 다고 하여 양육과 환경요인이 중요하지 않다는 의미는 아니 다. 세대를 이어 가족구성원이 $\mathrm{BPD}$ 의 병리를 물려받는다면 당연히 그 가족의 양육태도와 환경은 그 병리에 지대한 영 향을 받을 것이다. 유전적으로 병리소인을 타고나 대인관계 와 감정소통에 취약한 환자가 불안정하고 비공감적인 양육 환경의 영향으로 더욱 심한 병리를 가지게 된다. 이 질환의 유전성과 환경적 요소에 대해 치료자는 균형 있는 시각을 가 질 필요가 있다.

$\mathrm{BPD}$ 는 단독으로 진단되는 경우가 거의 없을 정도로 공존 질환 동반율이 높다(Zanariri 등 1998). 기분장애, 불안장애, 물질사용장애, 식이장애, 외상후스트레스장애(posttraumatic stress disorder, PTSD) 등이 흔히 동반된다. 동반질환의 심 각도에 따라서 $\mathrm{BPD}$ 보다 동반질환이 우선 치료되어야 하는 수가 있다. 제1형 양극성장애, 조절되지 않는 물질사용장애, 신경성 식욕부진, 복합 외상후스트레스장애(PTSD)가 동반 되었을 경우는 이들 질환에 대한 치료를 우선적으로 시행하 
고 $\mathrm{BPD}$ 의 치료를 병행해야 한다. 주요우울장애, 제 2 형 양극 성장애, 불안장애, 조절되는 물질사용장애, 신경성 대식증, 성인기 $\mathrm{PTSD}$ 를 동반할 경우에는 $\mathrm{BPD}$ 의 치료가 우선 되거 나 함께 병행되어야 하는데, $\mathrm{BPD}$ 의 병리가 이들 동반질환 의 경과에 영향을 주기 때문이다. 어떤 경우이든 $\mathrm{BPD}$ 의 진 단과 치료가 간과되어서는 안 된다. 동반질환을 주 진단으로 내세우고 $\mathrm{BPD}$ 진단을 축소하고 회피하는 경우에는 동반질 환과 $\mathrm{BPD}$ 의 경과 모두에 악영향을 미치게 된다.

$\mathrm{BPD}$ 의 자연경과에 대한 교육도 필요하다. Gunderson 등 (2011)과 Zanarini 등(2012)이 시행한 10년간의 전향적 연구에 서 $80 \%$ 가 10 년 후에는 충족되는 $\mathrm{BPD}$ 진단기준 항목이 2개 이하였다. 즉 관해되었다는 의미이다. 급성증상의 경우 치료 없이도 호전된다는 것이다. 이것이 치료가 불필요하다는 것 을 뜻하는 것은 절대 아니다. 효과가 입증된 정신치료의 경우 (DBT, MBT, TFP, GMP) 치료 3 6개월 내에 급성증상이 호 전되므로 치료를 할 경우에 환자의 삶이 훨씬 빨리 안정화될 수 있다. 이와 같이 급성증상의 호전을 목표로 한다면 $\mathrm{BPD}$ 의 치료가 반드시 장기적이거나 특수화된 집중치료일 필요 는 없다고 할 수 있다. 다만, 만성증상 즉 근본적인 병리로서 분리된 대상관계의 통합(split-off internalized, affectively invested object relations)을 통해 정체성을 확립하고 사회적 기능을 회복하는 것은 정신역동적 치료접근만이 효과가 있 었다(Kernberg와 Michels 2009).

위의 정보들을 한 번에 전달하는 것은 기법적으로 효과적 이지 않다. 예비면담 중에 각각의 내용을 시의적절하게 환자 나 보호자에게 전달하는 것이 좋다. 예비면담의 후반에는 $\mathrm{BPD}$ 의 치료선택지에 대해서도 교육하기를 권한다. 아래 적 합한 치료의 선택에서 설명하겠다.

일차적 가설의 공유

환자의 어려움과 병력에 대해 듣고 진단적 평가가 이루어 져 진단을 공유하고 질환에 대한 정보를 교육한 다음이나 아니면 진단을 공유한 직후에, 환자가 가진 어려움에 대해 치료자가 일차적으로 추정한 역동적 가설을 환자에게 설명 하는 것이 필요하다. 경험이 많은 치료자라면 각각의 환자에 게 맞춘 서사(narrative)를 통해 역동가설을 세울 수 있을 것 이다. 그러나 전공의나 초심자인 정신치료자에게는 환자의 이야기를 두세 시간 듣고나서 서사적 역동가설을 세우는 것 이 쉽지 않다. 이때 $\mathrm{GPM}$ 의 병리모델인 대인관계 과민감성 모델과 이에 바탕을 둔 대인관계 일관성 모델(Figure 1)을 틀로 하여 역동가설을 세운다면 $\mathrm{BPD}$ 환자 대부분이 공감할 수 있다. 앞에서 설명한 것과 같이 환자가 다른 사람과 연결 되어 있다고 느낄 때, 거절과 버림받을 위협을 느낄 때, 위협
을 느끼는 상태가 회복되지 않을 때 환자가 대인관계에서 반응하는 방식과 그것이 환자의 대인관계와 삶에 미치는 영 향을 환자에게 설명하고 교육한다. 치료자의 일차적 가설을 환자와 공유함으로써 환자가 자신을 어떤 방식으로 이해할 것인지 시범을 보여주는 것이 될 수 있고, 앞으로 치료가 무 엇을 목표로 할 것인지를 예견하게 한다. 이로써 환자는 치 료에 보다 더 참여할 동기를 얻게 될 수 있다.

\section{적합한 치료의 선택}

예비면담 기간 동안 환자의 출석과 치료에 대한 태도를 통해 치료동기를 평가할 수 있다. 또 직접 환자에게 치료동 기에 대해 물어볼 수 있다. 환자의 동기가 부족하다고 느낀 다면 치료를 보류하는 것을 고려해야 한다. 치료동기가 치료 의 효과를 예측하는 가장 강력한 인자 중의 하나이기 때문이 기도 하고, 환자가 치료를 강요받는다고 느끼고 억지로 치료 를 할 경우, 치료에 대한 부정적인 선입견이 생겨 향후 스스 로 동기를 가지고 치료를 시작할 가능성을 없애게 되기 때 문이다. 환자가 예비면담만으로 도움을 받았다고 느낄 수도 있다. 이 경우에도 무리하게 치료를 권유하는 것보다는 환자 의 판단을 존중하고 예비면담에서 이루어진 진단공유와 심 리교육, 일차적 가설의 설명만으로도 환자에게 많은 도움이 될 수 있다는 것을 인정할 필요가 있다.

예비면담으로 환자의 진단이 내려지고 증상의 심각도와 환자의 역동가설이 세워진 후에는, 환자가 동기가 있다면 적 합한 치료를 선택해야 한다. 환자가 자신의 치료에 어떤 선 택지가 있으며 각 치료가 어떤 특징이 있는지를 알고 선택 할 권리와 책임이 있다. 물론 치료자가 합리적인 이유를 설 명하면서 어떤 치료가 환자에게 가장 도움이 될 것으로 판 단하는지 설명하는 것은 매우 바람직하다.

$\mathrm{BPD}$ 에 효과가 입증된 치료는 정신치료적 접근이다. 효과 가 입증된 약물은 아직까지 없다. 정신치료적 접근에는 $\mathrm{DBT}$, $\mathrm{MBT}, \mathrm{TFP}, \mathrm{GPM}$ 과 같은 매뉴얼화된 정신치료가 있으며 정 신역동적 정신치료, 정신분석도 선택지 중의 하나이다.

환자가 이미 매뉴얼화된 특수정신치료를 경험했지만 부 족함을 느끼거나, $\mathrm{BPD}$ 의 치료가 처음이지만 심층적이고 근 본적인 치료를 원할 경우에는 정신역동적 정신치료를 제안 할 수 있다. 정신분석은 전공의나 초심자인 정신치료자가 시 행하기가 어렵다.

환자와 치료선택지를 논의하여 정신역동적 정신치료를 하기로 결정했다면, 이후 치료세팅에 대해 환자에게 설명한 다. 이 부분은 '치료세팅에 대한 유연한 자세'에서 설명하겠 다. 약물치료와 입원의 필요성은 신중하게 판단해야 한다. 크게 도움이 되지는 않으면서, 환자가 약물과 입원을 자신의 
문제의 해결책으로 삼고 회피하려고 하는 경향을 부추킬 수 있기 때문이다(Mercer와 Links 2019).

마지막으로 자해나 자살 위험에 대한 안전계획을 세운다. 환자 자신의 안전과 생명에 대한 책임이 스스로에게 있다는 것을 교육해야 한다. 자해나 자살 충동이 있을 때 효과적으 로 조절할 수 있는 예방수칙을 세우고, 필요하다면 그것을 문서로 만들어 환자와 보호자, 치료자가 나누어 가진다. 이 수칙을 지키는 것은 환자의 의무이며 소홀할 경우 치료시간 에 다루어야 할 주제가 된다.

병리가 가벼운 신경증 환자보다 $\mathrm{BPD}$ 환자에서는 예비면 담을 충분히 가지고 치료를 서두르지 않을 것을 권한다. 특히 전공의의 경우, 빨리 회기를 시작하려고 하는 경향이 있는데, 환자의 어려움을 잘 파악하고 환자를 잘 준비시킬수록 향후 의 치료가 더 효과적이다. 예비면담은 4 회에서 10 회까지도 가질 수 있으며, 이 시간을 일차적인 치료로 간주해도 무방하 다. 다시 한번 강조하건데, 정신과 전공의들이 $\mathrm{BPD}$ 환자를 예비면담을 하기도 전에 정신역동적 정신치료의 적응증으로 예단해서는 안 된다. 저자의 경험에서 $\mathrm{BPD}$ 환자들 중에 치 료를 시작하는 단계에서부터 정신역동적 정신치료가 적합한 경우는 드물었고, 지지적인 치료와 인지행동적 치료를 우선 적으로 필요로 하는 경우가 대다수이다. 이들 치료로 급성증 상이 호전된 이후에 지속적인 치료동기가 있는 경우 정신역 동적 정신치료의 적응증이 될 수 있으며, 또는 정신역동적 정 신치료를 위한 동기를 향상시키는 준비과정이 필요하다. 저 자는 이 과정을 확장된 예비면담 기간 동안 할 수 있다고 생 각하며, GPM의 모델을 적극 활용하기를 제안하는 것이다.

수퍼비젼

전공의나 경험이 부족한 치료자는 반드시 $\mathrm{BPD}$ 환자의 역 동적 정신치료 경험이 많은 치료자의 수퍼비젼을 받으면서 치료를 시행해야 한다. $\mathrm{BPD}$ 의 치료는 환자의 여러 측면을 균형 있는 시각으로 통합적으로 이해하고, 여러 치료접근법 을 절충하여 시행해야 하므로 많은 경험을 쌓은 치료자의 수퍼비젼은 매우 도움이 된다. 병리가 심한 환자일수록 치료 자에게 역전이 감정을 불러일으키는데 전공의나 경험이 적 은 치료자는 자신의 역전이 감정을 인지하고 이해하지 못할 경우가 많다. $\mathrm{BPD}$ 환자의 치료에서 역전이 감정을 잘 이해 하고 이용하는 것이 필수적이다.

\section{치료세팅에 대한 유연한 자세}

$\mathrm{BPD}$ 환자의 치료는 불가피하게 유연한 치료 세팅을 필요 로 한다. 환자의 동기와 준비상태에 따라 치료회수가 변동되 기도 하고 위기상황에서 치료자의 중립성을 일시적으로 포
기해야 하기도 하며, 보호자의 참여를 요청해야 할 경우도 생긴다. 하지만 치료 세팅의 유연성이 치료구조가 견고하지 않음을 의미하는 것은 아니다. 치료자는 BPD 환자를 치료 할 때 견고한 치료구조를 유지해야 한다(Kernberg 2004).

견고한 치료구조는 불안정한 환자를 붙들어 주는(holding) 기능을 한다. 견고한 치료구조를 유지하면서도, 실용적, 합리 적 이유로 치료의 세팅을 수정해야 할 때 유연한 자세를 가 질 필요가 있다. 즉, 환자와 합의하여 결정된 치료세팅을 환 자가 수정하기를 요청하거나, 치료자가 수정할 필요를 느낄 때, 환자의 내면 그리고 환자와 치료자의 관계의 측면에서 치료세팅 변경이 가지는 의미를 충분히 이해하는 작업을 해 야 한다. 예를 들어, 치료빈도를 줄이려는 것이 치료자를 낙 담시켜 자신의 좌절감과 무력감을 투사하는 환자의 무의식 적인 방어일 수 있다. 세팅의 수정을 결정하기 이전에 충분 히 환자-치료자 상호작용의 의미를 이해하고 환자에게 이 해를 전달하는 것이 필요하다. 하지만 치료자가 최종적인 결 정에 대해 선입견을 가지고 접근하지 않도록 해야 한다. 환 자는 저항할 권리가 있다. 환자의 저항은 환자가 치료과정 매 순간 얼마나 준비되어 있는지 측정할 수 있는 저울이기 도 하다. 세팅의 수정에 대해 치료자는 유연한 태도로 접근 하며 최종적인 결정은 환자와 충분한 논의를 통해 이루어져 야 한다. 이러한 태도가 궁극적으로 치료동맹을 강화시켜 향 후 치료의 결과에 긍정적으로 작용한다. 하지만 염두에 두어 야 할 것은 치료자가 환자의 의견에 동의하여 따르는 것이 아니라, 환자의 동기와 저항을 존중하여 합의한다는 것이다.

전공의의 경우, 치료기간에 대한 특수상황이 고려되어야 한다. 수련기간 이후 여러 이유로 환자를 더 오래 치료할 수 없는 경우가 있다. 이런 상황이 예견된다면 치료시작 전에 환자에게 자신이 언제까지 치료할 수 있는지, 그 이후의 치 료선택지를 알려주어야 한다. 환자가 그 이후까지 치료가 지 속되기를 원한다면, 치료자가 원격으로 치료를 이어가거나, 다른 치료자에게 연계할 수 있고 그 시점에서 환자와 다시 논의하여 결정할 것임을 알려야 한다.

치료자와의 치료종결 시점이 이미 결정이 되어 있는 전공 의와의 정신역동적 정신치료에서 환자와 치료자의 치료관 계 및 치료동맹 형성이 어려워질 것을 예상할 수 있다. 하지 만 전공의의 특수상황 또한 환자가 삶에서 맞이하게 될 현 실 중 하나일 뿐이며, 좌절의 경험을 재현하는 의미도 있을 수 있다. 치료자는 솔직하고 담대한 자세로 이 현실을 인정 하고 치료 전반에 걸쳐 환자가 좌절과 거절, 버림받는 느낌 에 보다 취약할 것을 염두에 두고 이 부분에 대한 작업을 피 해서는 안 된다. 적극적으로 작업한다면 이 취약점이 오히려 환자의 핵심 병리를 심도 깊이 조기에 다룰 수 있는 기회가 
되어 긍정적인 치료결과를 이끌 수 있다.

저자가 수퍼비젼한 증례 중에 한 예를 들어보겠다. 전공의 인 치료자는 $\mathrm{BPD}$ 환자를 처음 만났을 때 자신이 2년간 치료 할 수 있으며 그 이후 자신의 거취가 불확실하여 치료의 지 속여부를 확신할 수 없다고 알리며 치료를 시작했다. 환자는 어머니에게 매우 의존적이며 치료자를 신뢰하기 힘들어했 다. 1 년 6 개월의 치료과정 동안 점진적으로 어머니와 분리작 업이 이루어졌으며, 이와 동시에 치료자에 대한 의존도가 높 아지고 있었다. 전공의 치료자는 이 상황에서 환자에게 6개 월 뒤 치료가 중단될 수밖에 없는 상황을 다시 상기시켜야 할지가 고민이 되었다. 환자를 밀어낸다는 느낌을 주게 되어 치료관계가 파괴되거나 환자의 증상이 악화될 것이 염려되 었기 때문이다. 저자는 전공의에게 바뀔 수 없는 현실이고 그토록 염려가 되는 일이기에, 최대한 빨리 치료자와 환자의 대화의 중심에 두어서 충분히 환자가 이를 다룰 수 있도록 돕는 것이 최선이라고 조언했다. 환자의 병적 의존심(pathologic dependency)이 전공의로 하여금 전능환상(omnipotent fantasy)과 구원환상(rescue fantasy)이라는 역전이감정을 불 러일으켰을 것이라는 역동가설도 설명했다. 또 환자의 수동 공격성(passive aggression)을 피하고 싶은 치료자의 역전이 로 볼 수도 있었다. 이에 전공의는 환자에게 곧 자신의 상황 을 상기시키고 치료가 6개월 정도 가능하다고 설명했다. 환 자는 겉으로는 담담해 보였으나 그동안 정체되어 있었던 취 업문제에서 눈에 띄는 변화를 보이기 시작했다. 이후 취업활 동을 하느라 치료를 취소하는 등, 치료자와 치료로부터 멀어 지려는 시도도 보였다. 전공의 치료자는 환자의 변화를 치료 자의 상황에 의해 버림받는 느낌을 느끼는 피해사고(paranoid idea)로 인한 치료자에게 대한 분노와 저항의 표현이라 고 생각하고 다루었다. 그와 동시에 환자가 의존대상을 갈구 하면서 그와 분리되지 못하고 독립적인 주체가 되기가 어려 웠던 것을 현재 변화가 일어난 환자의 시점에서 되돌이켜볼 수 있었다. 이 과정 동안 환자는 치료자에게 버림받는 느낌 에서 치료자에게서 독립하는 과정으로 느끼는 인식의 변화 가 일어나게 되었다. 환자는 치료자가 제시한 시점보다 2주 앞서 치료를 종결하기를 원했고 치료자는 그렇게 하기로 환 자와 합의하였다.

Kernberg(2004)는 BPD의 정신역동적 정신치료로 주 3회 를 권유하고, 적어도 주 2 회를 유지할 것을 주장했다. 저자도 몇 해 전까지는 $\mathrm{BPD}$ 환자의 심한 병리를 고려했을 때, 주 1 회로는 환자의 불안정한 감정을 치료자가 담아주기가(contianing) 힘들고 환자의 부정적인 전이에 대한 작업을 하는 데 어려움이 있다고 생각하여 치료 시작부터 주 2 회를 제안 하는 것이 보통이었다. 그러나 실제 현장에서 만나는 BPD
환자들 중에 주 2 회의 정신치료를 선뜻 받아들이는 경우가 흔치 않았다. GPM의 핵심개념에서 주장하는 바와 같이 주 1 회의 일차적인 접근만으로도 $\mathrm{BPD}$ 환자의 급성기 증상은 효과적으로 호전이 된다는 점을 감안했을 때, 환자의 동기가 강하지 않다면 주 1 회의 정신역동적 정신치료로 치료를 시 작하는 것도 충분히 좋은 시작이라고 생각한다. 저자의 경험 에서는 주 1 회로 치료를 시작해도 급성기 증상의 호전은 충 분했고, 치료자가 환자의 의견을 존중하는 것으로써 향후 환 자의 치료동기를 강화시키는 데 도움이 되었다.

환자의 심층적 역동을 이해하고 환자-치료자의 상호작용 에서의 전이와 역전이를 이해하여 해석으로 전달하고 근본 적인 내적 변화에 이르기 위해서는 주 2회의 정신역동적 정 신치료가 가장 효율적인 것은 사실이다. GPM에 의하면 주 1 회로 치료를 시작하면서, 치료가 도움이 된다는 것이 확인 되면 주 2 회로 늘리는 것을 고려해보자고 선제적인 권유를 할 수도 있다. 이것은 치료자가 주 2 회의 정신역동적 정신치 료 빈도에 대해 강경한 입장을 취하고 주 1 회를 고집하는 환 자에게 주 1 회를 해보고 도움이 안 된다면 2회로 늘려야 한 다고 주장하는 것과는 사뭇 다른 접근이다. 도움이 안 되는 치료를 더구나 빈도를 늘려야 한다는 것을 흔쾌히 수용할 사람은 없다. 따라서 저자는 GPM이 치료빈도에 대해 취하 는 이런 유연한 자세가 매우 합리적이며 환자와의 치료동맹 에 긍정적인 효과가 있다고 생각한다.

만성적인 문제와 사회적 기능의 향상이 가능하기까지는 2 년 이상의 치료가 필요하다고 보지만, 치료를 시작하면서부 터 환자에게 치료기간을 2년 이상으로 명시하는 것은 바람 직하지 않다. 치료가 도움이 되고 환자의 동기가 유지된다면 치료는 수년이 지속될 수도 있지만, 치료가 효과적이지 않거 나 환자가 극복되기 힘든 저항감을 느낀다면 치료중단을 원 하는 환자의 의견을 수용하는 것이 낫다. 치료기간을 명시하 는 것이 환자의 저항을 극복하게 해주지는 않는다. 오히려 부담감을 느끼고 조기에 심한 저항을 불러일으킬 수 있다. 환자의 동기저하와 저항감으로 치료를 중단하게 될 경우, 환 자의 의견을 존중하되 향후 치료가 필요하다고 느낀다면 다 시 치료를 시작할 수 있고 치료자는 기다릴 것이라고 언급 하는 것이 향후 치료재개에 도움이 된다. $\mathrm{BPD}$ 환자의 치료 가 한 번에 이루어지기보다 수차례 치료의 중단과 재개가 반복되면서 서서히 환자가 저항감을 극복해 나가는 경우도 흔하므로, 치료가 중단될 경우 치료자가 실망하기보다 전체 치료과정의 한 부분으로 생각하는 것이 도움이 된다. 저자의 임상경험에서 여러 환자들이 수년에 걸쳐 치료를 시작하고 중단하기를 반복하는 것을 관찰하였다. 대체로 환자들은 자 신이 치료에 대한 저항이 극복할 수 없을 정도로 심해졌을 
때 치료자가 수긍하고 치료중단에 합의하면서도 언제라도 다시 시작하기를 원한다면 연락하라고 문을 열어두는 태도 에 치료자에대한 신뢰와 향후의 치료동기가 향상이 된다. 그 래서 후속된 치료에서는 조금더 협력적인 태도를 보이며 치 료의 성취도 높아진다.

신경증 환자의 정신역동적 정신치료와는 달리 $\mathrm{BPD}$ 환자 의 치료에서는 보호자의 협조가 필요할 수 있다. $\mathrm{BPD}$ 환자 의 치료는 대체로 부모가 치료비를 지원하는 경우가 많고 환자가 부모와 함께 생활하거나 부모에게 의존하여 생활을 유지하는 경우가 많다. 그래서 보호자가 치료과정에 대해 알 고 싶어한다면 예비면담 동안 부모와 면담을 따로 할 수 있 다. 이때 환자의 자해와 자살 위험에 대해서도 설명하고 안 전계획을 공유하고 환자의 안전에 대한 책임은 일차적으로 환자 본인에게 있다는 것을 교육하는 것이 좋다. 또 환자와 치료자가 치료시간에 나눈 이야기에 대해 비밀유지의 의무 가 있으며 치료가 시작된다면 보호자와 치료자가 연락이나 면담이 필요한 경우 반드시 환자에게 상의 후에 이루어질 것임을 설명해야 한다. 되도록이면 보호자와 치료자의 연락 은 최소화하는 것이 환자와 치료자의 치료동맹을 강화하는 데 도움이 된다는 것도 설명한다.

환자의 치료시간 외 연락에 대해서는 기본적으로 치료자 의 사적인 연락처를 알려주는 것은 불필요하다. 전공의의 경 우 불가피하게 치료약속 등으로 연락이 필요하여 개인연락 처를 알려주어야 하기도 하는데, 그 외의 용도로 사용하지 않 을 것을 당부해야 한다. 위급한 상황의 경우는 응급실을 찾도 록 교육한다. 환자가 위급 시에 자신의 안전을 치료자에게 맡 기기보다 스스로 대처하고 해결책을 찾는 것에 적응해야 한 다. 치료시간 사이 위급한 상황에서 스스로 대처할 수 없는 경우라면, 치료빈도를 늘리는 것이 도움이 될지 판단이 필요 하다. 그렇게 해서 도움이 되지 않는다면 정신역동적 정신치 료를 보류하고 보다 지지적이고 구조화된 치료법인 DBT나 입원치료를 고려해봐야 한다.

\section{적극적이고 공감적인 태도}

$\mathrm{BPD}$ 환자의 치료에서 치료동맹의 확립은 치료의 성패를 가름하는 핵심요소이다. 치료동맹을 공고히 하기 위해 $\mathrm{BPD}$ 환자의 치료자는 충분히 좋은 치료자(good-enough therapist)로서 자신감을 가지고 적극적인 태도로 치료해야 한다. 치료자의 적극성은 환자의 이야기를 경청하는 것에서부터 시작한다. 환자가 이야기하는 것을 표면적인 의미뿐 아니라 심층의 의미까지 이해하기 위해 충분히 이해하려는 자세로, 궁금한 마음을 가지고 적극적으로 질문하고 요약하면서 경 청하는 것이 필요하다. 환자의 이야기를 대강 이해해서는 안
되며 철저히 이해하겠다는 자세여야 한다. 이러한 태도에서 공감의 자세는 자연히 배어 나오고 치료동맹도 강화된다.

환자의 감정에 대한 공감은 지적인 능력으로 이루어지지 않고 환자와 치료자의 상호작용 속에서 무의식 중에 이루어 지는 경우가 많다. $\mathrm{BPD}$ 환자의 감정은 급격히 변하고 불안 정하다. 환자가 감정의 소용돌이에 빠져있을 때 치료자도 함 께 혼란스럽고 좌절감을 느끼게 된다. 섣불리 환자의 감정을 요약해서 해석해주려고 하기보다는 환자와 혼란스러운 시 간에 머물며 함께 하는 시간이 필요할 수도 있다.

신경증 환자의 정신역동적 정신치료에서 치료자의 자세 는 중립적이고 익명성을 견지하지만, $\mathrm{BPD}$ 환자의 치료에서 는 치료자가 종종 중립성과 익명성을 벗어나 자신의 의견을 드러내는 것이 필요할 수도 있다. 치료를 심각하게 위협하는 경우나 자신에게 매우 해로운 행동을 인식하지 못할 때 치 료자가 자신의 의견을 이야기하고 우려를 표현하는 것이 필 요하다.

\section{지금-여기와 전이해석}

정신역동적 정신치료는 환자가 자신의 내면을 심층적으 로 이해하도록 도와서, 궁극적으로 환자가 스스로 성찰하고 이해할 수 있는 능력을 가지고 자신의 정체성과 존재를 충분 히 인식하면서 주체적이고 책임감 있는 삶을 살도록 하는 것 이 목표이다. $\mathrm{BPD}$ 의 정신역동적 정신치료의 목표도 다르지 않다. 이 목표를 실현시키는 데 있어서 인지행동적 치료접근 이나 순수지지적인 치료접근은 한계가 있다는 것이 여러 연 구의 결과이다(Gabbard와 Horowitz 2009; Kernberg 2004; Kernberg와 Michels 2009). 정신역동적, 정신분석적 치료접 근만이 환자의 내면의 궁극적 변화를 가능하게 했다(Kernberg와 Michels 2009).

환자가 자신의 심층적 무의식적 내적현실을 이해하도록 하기 위해서, 정신분석적 방법론에서는 환자의 유아기 경험 의 재구성과 환자-치료자 상호관계의 해석이라는 큰 틀을 제시한다. 그런데 $\mathrm{BPD}$ 환자에게 고전적인 정신분석적 기법 에 따라 유아기의 경험을 재구성(reconstruction)하고 해석 하는 것에 초점을 맞추었을 때 오히려 환자의 증상이 악화될 수가 있다(Kernberg 2004; Kernberg와 Michels 2009). 특히 치료초반에 유아기 경험에 초점을 맞추면 환자는 자신의 문 제를 양육환경의 탓으로 돌리고 가족에게 분노를 표출하기 도 한다. 치료초기의 $\mathrm{BPD}$ 환자는 내적으로 편집분열 위치 (paranoid-schizoid position)에 있어서 과거의 경험을 현재 의 문제를 이해하기 위해 되돌아보는 것이 아니라, 현재 문 제에 대한 책임을 투사할 대상을 과거에서 찾으려고 하기 때문이다(Kernberg 2004). 이것을 유아기 경험에 대해서 이 
야기하는 것을 피하라는 의미로 이해해서는 안 된다. 환자의 어려움을 이해하기 위해 유아기 경험을 듣고 질문하는 것은 필요하다. 다만 유아기 경험을 재구성하는 것에 초점을 두어 작업하는 것이 도움이 되지 않는다는 의미이다.

지금-여기, 즉 치료자와의 상호작용에 보다 초점을 맞추는 것을 $\mathrm{BPD}$ 환자의 정신역동적 정신치료에서는 원칙으로 삼 는다(Gabbard와 Horowitz 2009; Kernberg 2004; Kernberg 와 Michels 2009). 대부분의 BPD 환자는 치료초기부터 치료 자에 대한 부정적인 전이를 표출하게 된다. 이 때문에 치료 동맹을 형성하는 데 큰 장애가 되곤 한다. 치료자는 환자가 표출하는 부정적 전이의 신호를 섬세하게 감지하고 신중한 탐색과 직면, 해석으로 신속하게 대처해야 한다. 치료자와의 관계에서 보이는 원초적인 방어기제(primitive defense mechanism), 즉 분리(splitting)와 투사적 동일시(projective identification), 이상화와 평가절하를 반복하는 패턴을 찾아내서 환자가 이해할 수 있도록 명료화하고 설명하고 해석한다 (Kernberg 2004).

전공의나 경험이 적은 치료자가 치료자-환자 상호관계에 서 전이를 읽어내는 것이 쉬운 일은 아니다. 적극적으로 찾 아내려고 하지 않는다면 경험이 적은 치료자에게 전이가 읽 히지 않을 것이다. 경험이 적은 치료자가 전이를 잘 읽을 수 있는 방법은 환자가 오늘 나에게 하는 이야기를 나에게 전 하는 메시지로 듣고 나에게 환자의 어떤 마음을 전하고 싶 은 것인지 궁금함을 가지고 듣는 것이다. 예를 들어, 한 $\mathrm{BPD}$ 환자가 세션에서 "엄마가 나한테 해주는 것이 많지만, 나는 엄마가 나를 사랑한다는 느낌이 안 들어요. 항상 엄마는 나 를 도와주고 싶다고 해요. 나를 학교에 태워주고 학원도 알 아봐주죠. 내 방도 청소하고 나를 깨우고 $\cdots$. 하지만 나는 엄 마가 나를 관리한다는 생각이 들어요. 자기 기준에 맞도 록...”이라고 이야기를 했다. 이렇게 환자가 어머니가 자신 을 진심으로 사랑하기보다는 어머니의 기대에 맞추기를 바 라는 것 같아서 실망스럽고 화가 난다는 이야기를 할 때, 치 료자는 이 이야기를 어머니와의 관계로만 듣지 않고, 환자가 치료자도 자신을 얼마나 진심으로 걱정하는지, 자신을 있는 그대로 바라보는지 궁금하고 그렇게 해주기를 바라는 마음도 함께 전달하고 있다고 생각할 수 있다. 이때 치료자는 " $\bigcirc \bigcirc$ 씨는 어머니가 $\bigcirc \bigcirc$ 씨를 얼마나 있는 그대로 존중하고 진심 으로 사랑하는지에 대해서 의문이 들고, 어머니가 자신이 원 하는 딸이 되는 것을 원할 뿐이라는 생각이 들어서 매우 서 운하고 화도 나는 것 같네요. 아마 $\bigcirc \bigcirc$ 씨가 저에게 원하는 것도 어머니에게 원하는 것과 같이 $\bigcirc \bigcirc$ 씨를 있는 그대로 존중하고 진심으로 위했으면 하는 것이 아닐까 싶어요.”라 고 해석할 수 있다.
환자가 외부적으로 인식하는 경험은 내적 현실의 외현화 (externalization)라고 보는 것이 역동적인 이해의 관점이다 (Kernberg 2004). 그러므로 환자가 치료자에게 이야기하는 외부의 현실은 모두 자신의 내적인 환상과 갈등을 표현하는 것으로 현실몽 (manifest dream)과 같다. 치료자는 환자의 이 야기에서 환자의 내적 현실을 볼 수 있어야 한다.

환자의 내적현실을 치료자와의 상호관계의 맥락에 비추 어 해석하는 것이 매우 중요하다. 치료자와 환자의 상호관계 는 환자의 내적 현실을 드러내는 스크린과 같다. 무의식적인 대상관계와 표상들의 이미지가 치료자-환자 관계에 투영된 다. 치료자는 이를 읽어내고 이해하여 환자에게 해석하여, 환 자가 자신의 내적현실을 이해하고 성찰할 수 있도록 돕는다. 이는 신경증 환자의 치료에서 치료자가 하는 역할과 일치한다.

환자의 성찰능력이 향상된 치료 중후반기에는 유아기의 경험을 재구성하고 해석하는 것이 도움이 될 수 있다.

\section{실생활의 문제점에 초점}

환자의 실생활에서의 문제점에 초점을 맞추라는 원칙은 지금-여기에 초점을 맞추라는 원칙과 상호모순되는 것으로 생각할 수도 있는데, $\mathrm{BPD}$ 환자의 정신역동적 정신치료에서 치료자는 외부현실과 환자의 내적현실에 대해 균형 잡힌 시 각으로 접근해야 한다. 이것이 진정한 중립적인 자세라고 할 수 있다.

환자는 대인관계와 직업에서 현실적인 장애를 겪고 있으 므로 이에 대한 관심을 유지하고 필요시 적극적이고 심지어 선제적인 태도로 논의하고 조언하는 것이 필요할 수 있다. 특히 환자의 현실적인 문제가 치료에 위협이 되거나 환자에 게 매우 부정적인 결과로 이어질 수 있는 데도 환자가 인식 하지 못하고 있을 때, 치료자가 그 부분을 선택적으로 초점 을 맞추고 자신의 의견을 밝히는 것이 필요할 수 있다. 환자 가 자신이나 타인에게 위험한 행동을 하려고 하거나, 치료를 방해하는 행동(잦은 결석이나 지각, 의도적으로 숨기거나 거짓말 등), 일상생활을 전반적으로 해치는 행동을 보일 때 는 이러한 문제를 우선적으로 다루어야 한다.

$\mathrm{GPM}$ 은 '사랑 이전에 일'이라고 환자에게 교육한다. $\mathrm{BPD}$ 환자들은 자신의 삶에서 주도적이고 주체적이기보다, 관계 에 매달려 의존적이고 수동적인 태도를 보인다. 환자가 자신 의 삶에 책임감 있는 자세로 주체적인 존재가 되기 위해서는 학업과 직업의 성취가 필수조건이므로 환자가 관계와 성취 에서 균형 있는 시각을 유지할 수 있도록 도와야 한다(ChoiKain과 Gunderson 2019a). 


\section{역전이}

$\mathrm{BPD}$ 환자는 자신의 감정을 스스로 담아두지(containing) 못하는 경우가 많으므로 그 감정을 치료자에게 투사하게 되 고, 치료자는 강한 역전이 감정에 휩싸이게 될 때가 많다. 치료 자가 자신의 역전이 감정을 잘 인식하지 못하고 있으면 치료 를 방해하는 역전이 상연으로 이어지고 치료를 위험하게 만들 수 있다. 환자의 all or none의 흑백논리가 치료자에게 투사되 어 치료자가 완전하게 헌신적이지 않으면 좋은 치료자가 아니 라고 비난받을까봐 환자의 요구를 계속 들어주게 된다든지, 환자가 자신의 좌절감과 무가치함을 치료자에게 투사하여, 치 료자가 치료에서 좌절감과 열등감을 느껴 이에 대한 반대급 부로 환자가 방어적으로 다 좋아졌다고 하는 말을 치료자가 무비판적으로 믿으려고 하는 등을 예로 들 수 있겠다.

그러므로 치료자는 치료과정에서 자신의 감정을 잘 따라 가면서 살펴야 한다. 역전이 감정을 인식했을 때, 환자와의 관계에서 어떤 상호작용이 일어나고 있는지 이해하면 환자 의 역동을 더 공감하고 이해하는 데 큰 도움이 된다. 전공의 나 초심자인 정신치료자는 경험이 부족하여 역전이 감정을 탐색하고 이해하는 것이 어려운 일이다. 그러므로 수퍼비젼 이 꼭 필요하다. 수퍼비젼은 자신이 인식하지 못하는 역전이 감정과 환자와의 상호작용을 이해하는 데 매우 중요하다.

\section{여러 이론에 열린 자세}

여러 정보와 새로운 지식에 수용적이고 포괄적인 자세를 가져야 한다. 지금까지 $\mathrm{BPD}$ 환자가 어떤 치료로 호전을 보 였을 때, 치료인자가 무엇인지 명확하게 설명할 수 있는 포 괄적인 단독 이론은 없다(Livesley 2012). 그러므로 어떤 이 론이 환자를 도울 수 있는지에 대해서 항상 수용적일 필요 가 있다. $\mathrm{BPD}$ 환자의 치료는 여러 이론과 관점에 대해 유연 하고 절충적이어야 한다.

\section{결 론}

정신역동적 정신치료는 $\mathrm{BPD}$ 의 근본적인 치료로 여전히 중요한 위치에 있으며, 정신과 전공의가 수련과정 중에 정신 역동적 정신치료를 필히 수행해야 하는데 대상 환자들의 대 다수가 $\mathrm{BPD}$ 환자이다. 지금까지는 $\mathrm{BPD}$ 환자를 위한 수정 된 정신역동적 정신치료의 원칙이 명확하고 실용적이지 않 아 많은 치료자들이 어려움을 겪고 있다. 저자는 전공의와 경험이 부족한 정신치료자들을 위한 $\mathrm{BPD}$ 의 정신역동적 정 신치료의 수정된 원칙의 필요성을 절감해왔다.

과거의 $\mathrm{BPD}$ 에 대한 오해와 낙인은 과학적인 연구의 성과 와 임상적 경험의 축적으로 많은 부분 해소되었다. 10 년 자
연호전율이 $80 \%$ 에 이르는 $\mathrm{BPD}$ 의 자연경과와 일차적 치료 접근법이 특수치료에 비해 치료효과가 못하지 않다는 연구 결과가 $\mathrm{BPD}$ 는 치료하기 힘들고 장기간의 특수치료가 필요 하다는 편견을 해소했다. 좋은 정신과적 관리는 $\mathrm{BPD}$ 의 편 견과 미신에서 벗어나, 이 질환이 치료가 가능하고, 급성 증 상은 일차적, 일반적인 치료로도 충분히 치료효과를 볼 수 있다는 개혁적인 인식을 가져왔다.

그러나 만성적 장애의 치료와 근본적인 내적 변화를 원하 는 환자는 일반적 치료나 매뉴얼화된 정신치료법으로는 만 족할 만한 호전을 얻을 수 없다. 정신역동적 정신치료는 $\mathrm{BPD}$ 환자가 자신의 내면을 심층적으로 이해하여 궁극적인 성격 의 변화, 정체성과 주체성을 확립하도록 도울 수 있는 치료로 여전히 $\mathrm{BPD}$ 의 치료로서 중요한 위치에 있다. 다만 치료자의 익명성을 강조하는 고전적인 정신분석적 방법은 $\mathrm{BPD}$ 환자 를 오히려 악화시킬 수 있어서, 치료 방법론적인 수정을 필요 로 한다. Otto Kernberg가 제안한 수정된 정신역동적 정신치 료의 원칙이 있으나 실제 임상에 적용하기 위해서는 보다 구 체적이고 실용적인 방법론이 필요하다.

$\mathrm{GPM}$ 의 일차적이고 절충적인 접근법은 정신역동적 정신 치료와도 매우 효율적으로 절충, 통합될 수 있다. GPM의 진 단공개와 심리교육을 강조하는 실용적인 방법과 대인관계 과민감성이라는 병리모델은 정신역동적 정신치료의 예비면 담 기간에 환자가 자신의 질환에 대해 정확하고 유용한 정 보를 얻고 스스로를 성찰하고 이해하여 필요한 치료에 보다 적극적으로 참여할 수 있도록 준비시키는 효과가 있다. 또 $\mathrm{GPM}$ 의 치료세팅에 대한 유연한 태도도 경계성 성격장애의 정신역동적 정신치료에 접목했을 때 합리적이고 현실적인 접근을 하는 데 도움이 된다.

$\mathrm{GPM}$ 의 핵심 개념과 정신을 정신역동적 정신치료에 접목 한다면 역동적 정신치료을 $\mathrm{BPD}$ 의 치료에 적합하게 수정하 는 데에 매우 실용적인 방법론이 될 것이다. 예비면담 기간 을 활용하여 GPM적 치료접근을 할 수 있고, 이로써 환자가 자신의 질환에 대해 정확하고 명확한 이해와 성찰을 하고 치 료자와의 치료동맹을 조기에 형성하여, 다음 단계의 치료에 보다 수용적이고 적극적으로 참여하게 한다. 그리고 환자에 게 진단을 공개하여 협력적인 논의 과정을 거치고, 정신역동 적 정신치료의 세팅에 관하여 $\mathrm{GPM}$ 의 유연한 태도를 적용한 다면 전공의나 초심자인 치료자가 $\mathrm{BPD}$ 환자의 정신역동적 정신치료를 효과적으로 시행하는 데 큰 도움이 될 것이다.

\section{Acknowledgments}

None

\section{Conflicts of Interest}

The author has no potential conflicts of interest to disclose. 


\section{ORCID iD}

Chang-Hun Lee https://orcid.org/0000-0002-3091-7966

\section{REFERENCES}

American Psychiatric Association. Diagnostic and statistical manual of mental disorders. 4th ed. Washington, DC: American Psychiatric Press; 1994

Bateman AW. Treating borderline personality disorder in clinical practice. Am J Psychiatry 2012;169:560-563.

Bateman A, Fonagy P. Psychotherapy for borderline personality disorder: mentalization based treatment. Oxford: Oxford University Press;2004.

Bateman A, Fonagy P. 8-year follow-up of patients treated for borderline personality disorder: mentalization-based treatment versus treatment as usual. Am J Psychiatry 2008;165:631-638.

Bateman A, Fonagy P. Mentalization-based treatment for personality disorders: a practical guide. Oxford: Oxford University Press;2016.

Bender DS, Dolan RT, Skodol AE, Sanislow CA, Dyck IR, McGlashan TH, et al. Treatment utilization by patients with personality disorders. Am J Psychiatry 2001;158:295-302.

Behavioral Tech. Level 3-comprehensive training standard DBT. [cited 2021 Apr 11]. Available from: https:/behavioraltech.org/training/ training-catalog/level-3.

Choi-Kain LW, Gunderson JG. Applications of good psychiatric management for borderline personality disorder: a practical guide. Washington, DC: APA Publishing;2019a.

Choi-Kain LW, Gunderson JG. Preface. In: Choi-Kain LW, Gunderson JG, editors. Applications of good psychiatric management for borderline personality disorder: a practical guide. Washington, DC: APA Publishing; 2019b. p.xv-xix.

Clarke M, Hafner RJ, Holme G. Borderline personality disorder: a challenge for mental health services. Aust N Z J Psychiatry 1995;29:409414.

Davidson KM, Tyrer P, Norrie J, Palmer SJ, Tyrer H. Cognitive therapy v. usual treatment for borderline personality disorder: prospective 6-year follow-up. Br J Psychiatry 2010;197:456-462.

Gabbard GO, Horowitz MJ. Insight, transference interpretation, and therapeutic change in the dynamic psychotherapy of borderline personality disorder. Am J Psychiatry 2009; 166:517-521.

Gunderson JG, Herpertz SC, Skodol AE, Torgersen S, Zanarini MC. Borderline personality disorder. Nat Rev Dis Primers 2018;4:18029.

Gunderson JG, Links P. Handbook of good psychiatric management for borderline personality disorder. Washington, DC: American Psychiatric Publishing;2014.

Gunderson JG, Lyons-Ruth K. BPD's interpersonal hypersensitivity phenotype: a gene-environment-developmental model. J Pers Disord 2008;22:22-41.

Gunderson JG, Stout RL, McGlashan TH, Shea MT, Morey LC, Grilo $\mathbf{C M}$, et al. Ten-year course of borderline personality disorder: psychopathology and function from the Collaborative Longitudinal Personality Disorders study. Arch Gen Psychiatry 2011;68:827-837.

Haskayne D, Hirschfeld R, Larkin M. The outcome of psychodynamic psychotherapies with individuals diagnosed with personality disorders: a systematic review. Psychoanal Psychother 2014;28:115-138.

Hersh RG. 15. Integration with transference focused psychotherapy. In: Choi-Kain LW, Gunderson JG, editors. Applications of good psychiatric management for borderline personality disorder: a practical guide. Washington, DC: APA Publishing;2019. p.327-349.

Kernberg OF. Borderline conditions and pathological narcissism. New York, NY: Jason Aronson;2004.

Kernberg OF, Michels R. Borderline personality disorder. Am J Psychiatry 2009;166:505-508.

Kessler RC, Zhao S, Katz SJ, Kouzis AC, Frank RG, Edlund M, et al. Past-year use of outpatient services for psychiatric problems in the Na- tional Comorbidity Survey. Am J Psychiatry 1999;156:115-123.

Knight RP. Borderline states. Bull Menninger Clin 1953;17:1-12.

Linehan MM. Cognitive-behavioral treatment of borderline personality disorder. New York, NY: Guilford Press;1993.

Livesley WJ. Moving beyond specialized therapies for borderline personality disorder: the importance of integrated domain-focused treatment. Psychodyn Psychiatry 2012;40:47-74.

McMain SF, Links PS, Gnam WH, Guimond T, Cardish RJ, Korman $\mathbf{L}$, et al. A randomized trial of dialectical behavior therapy versus general psychiatric management for borderline personality disorder. Am J Psychiatry 2009; 166:1365-1374.

McMain SF, Guimond T, Streiner DL, Cardish RJ, Links PS. Dialectical behavior therapy compared with general psychiatric management for borderline personality disorder: clinical outcomes and functioning over a 2-year follow-up. Am J Psychiatry 2012;169:650-661.

Mercer D, Links PS. 9. Psychopharmacologist. In: Choi-Kain LW, Gunderson JG, editors. Applications of good psychiatric management for borderline personality disorder: a practical guide. Washington, DC: APA Publishing; 2019. p.187-211.

Mercer D, Links PS, Sonley AK, Ilagan G, Choi-Kain LW. 13. Integration with dialectical behavior therapy. In: Choi-Kain LW, Gunderson JG, editors. Applications of good psychiatric management for borderline personality disorder: a practical guide. Washington, DC: APA Publishing;2019. p.281-304.

Narrow WE, Regier DA, Rae DS, Manderscheid RW, Locke BZ. Use of services by persons with mental and addictive disorders. Findings from the National Institute of Mental Health Epidemiologic Catchment Area Program. Arch Gen Psychiatry 1993;50:95-107.

Oldham JM, Skodol AE. Personality disorders in the public sector. Hosp Community Psychiatry 1991;42:481-487.

Olfson M, Pincus HA. Outpatient psychotherapy in the United States, II: patterns of utilization. Am J Psychiatry 1994;151:1289-1294.

Perry JC, Cooper SH. Psychodynamics, symptoms, and outcome in borderline personality disorders and bipolar type II affective disorder. In: McGlashan TH. The borderline: current empirical research (No. 1). Washington, DC: American Psychiatric Press;1985. p.19-41.

Reichborn-Kjennerud T, Ystrom E, Neale MC, Aggen SH, Mazzeo SE, Knudsen GP, et al. Structure of genetic and environmental risk factors for symptoms of DSM-IV borderline personality disorder. JAMA Psychiatry 2013;70:1206-1214.

Skodol AE, Buckley P, Charles E. Is there a characteristic pattern to the treatment history of clinic outpatients with borderline personality? J Nerv Ment Dis 1983;171:405-410.

Stoffers J, Völlm BA, Rücker G, Timmer A, Huband N, Lieb K. Pharmacological interventions for borderline personality disorder. Cochrane Database Syst Rev 2010;6:CD005653.

Yeomans FE, Clarkin JF, Kernberg OF. Transference-focused psychotherapy for borderline personality disorder: a clinical guide. Washington, DC: American Psychiatric Publishing;2015.

Zanarini MC, Frankenburg FR, Dubo ED, Sickel AE, Trikha A, Levin A, et al. Axis I comorbidity of borderline personality disorder. Am J Psychiatry 1998;155:1733-1739.

Zanarini MC, Frankenburg FR, Reich DB, Fitzmaurice G. Time to attainment of recovery from borderline personality disorder and stability of recovery: a 10-year prospective follow-up study. Am J Psychiatry 2010;167:663-667.

Zanarini MC, Frankenburg FR, Reich DB, Fitzmaurice G. Attainment and stability of sustained symptomatic remission and recovery among patients with borderline personality disorder and axis II comparison subjects: a 16-year prospective follow-up study. Am J Psychiatry 2012;169:476-483.

Zimmerman M, Mattia JI. Differences between clinical and research practices in diagnosing borderline personality disorder. Am J Psychiatry 1999;156:1570-1574. 